\title{
The combined effect of climate oscillations in producing extremes: the 2020 drought in southern Brazil
}

\section{O efeito combinado de oscilações climáticas na produção de extremos: a seca de 2020 no Sul do Brasil}

Alice Marlene Grimm ${ }^{1}$ (D), Arlan Scortegagna Almeida ${ }^{2}$, Cesar Augustus Assis Beneti ${ }^{2}$ \& Eduardo Alvim Leite ${ }^{2}$

${ }^{1}$ Universidade Federal do Paraná, Curitiba, PR, Brasil

${ }^{2}$ Sistema de Tecnologia e Monitoramento Ambiental do Paraná, Curitiba, PR, Brasil

E-mails: grimm@fisica.ufpr.br (AMG), arlan.scortegagna@simepar.br(ASA), cesar.beneti@simepar.br (CAAB), eduardo.alvim@simepar.br (EAL)

Received: July 17, 2020 - Revised: September 29, 2020 - Accepted: October 02, 2020

\begin{abstract}
The 2020 drought in southern Brazil, which culminated in late summer and early autumn (February-March-April), displayed one of the most deficient rainfall totals in such trimester. This period of the year has already been dominated by negative rainfall deviations since the end of the 1990s. This recent drought represents, therefore, a significant worsening in an already unfavorable situation of water availability. Such long-term behavior is due to the combination of opposite phases of two interdecadal oscillations in the sea surface temperature: the positive phase of the Atlantic Multidecadal Oscillation and the negative phase of the Pacific Interdecadal Oscillation. This combination produces variation in the atmospheric basic state that favors less rainfall in southern Brazil at this time of the year and more frequent occurrence of droughts. For an extreme event to occur, it is usually necessary that, in addition to interdecadal oscillations, an interannual oscillation event occurs that also favors drought, such as the events of Central El Niño in 2020 and La Niña in 2009 and 2012, years of droughts in southern Brazil during the same phase combination of the two interdecadal oscillations. Anthropic climate changes can intensify the frequency and intensity of these extreme events.
\end{abstract}

Keywords: Extreme drought; Combination of climate oscillations.

\section{RESUMO}

A seca de 2020 no Sul do Brasil, que culminou no final do verão e início do outono (fevereiro-março-abril), apresentou um dos mais deficientes totais pluviométricos em tal trimestre. Tal período do ano já vinha apresentando predominância de desvios pluviométricos negativos desde o final dos anos 1990. Esta recente seca representa, portanto, piora significativa num quadro já desfavorável de disponibilidade hídrica. Tal comportamento de longo prazo deve-se à combinação de fases opostas de duas oscilações climáticas interdecadais na temperatura da superfície do mar: a fase positiva da Oscilação Multidecadal do Atlântico e a fase negativa da Oscilação Interdecadal do Pacífico. Tal combinação produz variação no estado básico da atmosfera que favorece estiagem no Sul do Brasil nessa época do ano e a ocorrência mais frequente de secas. Para que ocorra um evento extremo, geralmente é necessário que, em adição a oscilações interdecadais, ocorra um evento de oscilação interanual que também favoreça a seca, como os eventos de El Niño Central em 2020 e La Niña em 2009 e 2012, anos de secas no Sul do Brasil durante a mesma combinação de fases das duas oscilações interdecadais. Mudanças climáticas antrópicas podem intensificar a frequência e intensidade destes eventos extremos.

Palavras-chave: Seca extrema; Combinação de oscilações climáticas. 


\section{INTRODUCTION}

\section{The 2020 drought and its impacts}

The trimester February-March-April (FMA) 2020 was a very dry period in southern Brazil, also preceded by some dry months in the previous year, especially in late austral winter and early spring. It was one of the worst ever droughts in the region, which affected several sectors, such as agriculture, hydropower generation and water supply to the population.

At the institutional level, the drought in southern Brazil was recognized in March 2020. Earlier that month, the National Water Agency (ANA), which is the Brazilian federal regulator, summoned water resources agencies and stakeholders from the three southern states (Paraná, Santa Catarina and Rio Grande do Sul) to a crisis room where regular meetings were held. The National Center for Monitoring and Alerts of Natural Disasters (Cemaden) was assigned to survey the drought from the meteorological perspective. In March 2020, Cemaden verified a widespread drought in the southern states with intensity ranging from weak to extreme, according to its Integrated Drought Index (IIS), which is calculated based on data from the previous six months (Centro Nacional de Monitoramento e Alertas de Desastres Naturais, 2020a). From the hydrological perspective, the problem was first observed through monitoring made by the hydropower sector, as monthly natural inflows to the Subsystem South were below $70 \%$ of long-term averages since July 2019, despite a mild recovery in November of that year (Operador Nacional do Sistema Elétrico, 2020a). Electricity supply in Brazil depends on the National Interconnected System (SIN), which comprises four subsystems, with Subsystem South encompassing the three above-mentioned southern states.

The impacts on the hydropower sector were evident in the drainage basins of Iguaçu and Uruguay rivers, which account for about $80 \%$ of the energy storage capacity of Subsystem South. In May 2020, inflows reached historical minima in the reservoirs of hydroelectric power plants Governador Bento Munhoz (since 1930) and Barra Grande (since 1964), these two containing the largest reservoirs in Iguaçu and Uruguay rivers respectively, which reveals the severity of the hydrological drought. In both cases, the analyzed data corresponded to 7-days averages of streamflows recorded at gauges located immediately upstream of the reservoirs, in locations not influenced by reservoir operations, at stations codes 65310000 and 70200000 of the National Water Agency information system (Agência Nacional de Águas, 2020). As a result of low inflows and reservoir depletion, the first half of May saw an alarming energy storage of only 14\% in Subsystem South capacity (Operador Nacional do Sistema Elétrico, 2020b).

Despite critical hydrometeorological conditions, the impacts on the hydropower sector were mitigated by the very existence of the SIN. Due to the fact that hydrometeorological conditions were favorable in other parts of the country, energy could be transferred from the remaining subsystems while generation was reduced, or even interrupted, and allowed water to be stored in Subsystem South reservoirs. Moreover, due to SARS-CoV-2 pandemic, energy demand has decreased after March 2020. This allowed, for example, Governador Bento Munhoz Hydroelectric Plant to recover its storage above $50 \%$ in early July of the same year (Companhia
Paranaense de Energia Elétrica, 2020). Conversely, water supply reservoirs suffered a dramatically reduction in its storage, possibly enhanced by the pandemic and increase in domestic use. Following a quarter with precipitation anomalies ranging from $-30 \%$ to $-70 \%$, in May 2020 the government of Paraná decreed a state of emergency for 180 days due to drought. On early July 2020, rotating water supply interruptions, with duration of a few days, were still being faced by 3.5 million inhabitants of the Metropolitan Region of Curitiba, capital of Paraná state.

Regarding drought impacts on agricultural sector, significant losses in soybean, corn and common bean crops occurred in the South Region, although heterogeneously among the three states. By the end of May 2020, the state most affected had been Rio Grande do Sul (Centro Nacional de Monitoramento e Alertas de Desastres Naturais, 2020b, 2020c). Its average yield in soybean, corn and common bean fell, respectively, 33\%,19\% and $12 \%$ in the quarter March-April-May of 2020, when compared to the same period of the previous year (Instituto Brasileiro de Geografia e Estatística, 2020). Rice production, which is the state's second most important crop after soybean, was not affected. However, the intense consumptive demand for irrigation of rice paddies has caused conflicts regarding the fulfillment of multiple uses of water, as was reported by the Secretariat for the Environment and Infrastructure of Rio Grande do Sul (Sema-RS).

In view of all the impacts caused by this drought, it is important to disclose its possible origins, so that water managers can be aware of the causes and mechanisms that can produce severe droughts and extreme rainfall events, and realize that extremes may happen beyond those limits already observed within the usually short period of available data. Therefore, some climate oscillations will be presented in the following.

\section{The importance of climate oscillations}

Natural climate oscillations are important ingredients for both extreme drought and precipitation events (Grimm \& Tedeschi, 2009; Tedeschi et al., 2015, 2016; Grimm et al., 2016). Certain phase combinations of climate oscillations from different origins and time scales (interdecadal, interannual and intraseasonal) can produce intense and persistent droughts or cause extreme precipitation by intensifying and anchoring synoptic patterns in certain regions.

Precipitation over South America, and Brazil in particular, is significantly impacted by the most important interannual climate oscillation, El Niño-Southern Oscillation (ENSO) (Grimm, 2003, 2004, 2011; Tedeschi et al., 2015, 2016; Cai et al., 2020). In addition, it also displays interdecadal variability produced by the main global and regional climate oscillations in this time scale, especially the Atlantic Multidecadal Oscillation (AMO) and the Interdecadal Pacific Oscillation (IPO) (Grimm \& Saboia, 2015; Grimm et al., 2016). Although a very significant contribution is also provided by intraseasonal time scales, such as the Madden Julian Oscillation (Grimm, 2019), in the present case study of the severe and persistent drought over southern Brazil that culminated at the austral late summer and early autumn of 2020, the focus will be on the longer time scales. 
ENSO is a coupled ocean - atmosphere climate oscillation. Its opposite phases, the events El Niño and La Niña, denote sea surface temperature (SST) conditions that are, respectively, above and below average in the central/eastern tropical Pacific, in addition to anomalies of atmospheric circulation coupled with them. This is the main climate oscillation on interannual time scales, with global climate impacts, including significant effects on South America. They can be produced directly, as on the west coast of the continent, which experiences the local effects of the perturbed SST, as well as indirectly, through atmospheric teleconnections from the Pacific, which disturb the atmospheric circulation over the continent, changing precipitation and temperature (Cai et al., 2020, and references therein).

El Niño (La Niña) events, despite having in common persistent above (below) normal SST in the equatorial CentralEastern Pacific, exhibit differences between them related to the distribution of these equatorial SST anomalies (Kao \& Yu, 2009; Tedeschi et al., 2015, 2016; Cai et al., 2020). Such anomalies may extend from the Central Pacific to the east, till the coast of South America, or they may be more concentrated in the Central Pacific. Therefore, El Niño (La Niña) events are classified into East El Niño (EEN) and Central El Niño (CEN) (East La Niña and Central La Niña), according to the location of the strongest SST anomalies in the east or central equatorial Pacific Ocean.

If SST anomalies have different distributions, their effects can also be different. The impact of ENSO on precipitation in southern Brazil is produced by tropic-extratropic atmospheric teleconnections, due to the propagation of Rossby waves produced in the tropics/subtropics (Grimm \& Silva Dias, 1995; Cai et al., 2020). In El Niño, for example, the anomalous warming of the equatorial ocean surface increases evaporation and heats the air above, increasing atmospheric instability and favoring the formation of deeper clouds in the equatorial Central-East Pacific, where convection is usually weak, due to the lower climatological SST. The formation of these deeper clouds and, therefore, greater transformation of water vapor into liquid water, produces anomalous release of latent heat in the atmosphere, constituting a source of energy that produces expansion of the atmospheric column and divergence at high levels (next to the tropopause). The air that diverges at high levels towards different latitudes undergoes variation of the Coriolis force, which produces the so-called Rossby waves, composed of centers of low and high pressure, or centers of cyclonic and anti-cyclonic circulation. The propagation of these waves does not occur equally in all directions. There are preferential routes, depending on where the forcing of the Rossby wave is, and some of them pass over southern South America, perturbing the atmospheric circulation and producing droughts or periods of longer and more intense rain (e.g., Grimm \& Ambrizzi, 2009). These perturbations can be different, depending on the position of the main forcing in the tropical Pacific Ocean, which can vary according to the position of the main anomalies of SST (Grimm \& Silva Dias, 1995).

The AMO describes the SST variations in the North Atlantic Ocean with multidecadal variability in an approximate $65-70$ years cycle. The overall physical mechanism that drives the variability in AMO is not yet well understood, but modeling studies indicate that the SST variation in the Atlantic is associated with variations in the Atlantic Meridional Overturning Circulation, formed by the transport of the top layer warm and salty oceanic water from the equatorial to North Atlantic region followed by the flow of deep cold water southward (Knight et al., 2005; Parker et al., 2007). This meridional circulation is enhanced (weakened) during the AMO positive (negative) phase.

The IPO is a wide Pacific basin decadal to multidecadal oscillation that displays some geographical similarity to ENSO except that the meridional scale of tropical anomalies is broader (Power et al., 1999; Parker et al., 2007). There are, however, differences with respect to ENSO: the tropical SST anomalies associated with the IPO extend further west and are relatively weak in the far eastern tropical Pacific. Besides, unlike ENSO, the opposite SST anomalies in the midlatitude North Pacific associated with the IPO are comparable to those near the equator, constituting an important component of this oscillation.

There are several hypotheses on the origins of IPO, including stochastic atmospheric forcing, SST advection associated with the North Pacific gyre oscillation or upper-ocean circulation, SST anomalies reinforced by unstable midlatitude ocean-atmosphere interaction, and mechanisms based on wind-driven upper-ocean circulation (Yang et al., 2020, and references therein). Modeling experiments based on this last hypothesis, recently suggested the AMO to be the source of the winds that can induce the IPO pattern, so that a positive AMO leads negative IPO by 4-8 years (Yang et al., 2020).

\section{Objectives}

This article intends to show that different natural climate oscillations contributed to the occurrence of the severe drought in the late summer and early autumn of 2020 in southern Brazil, and therefore emphasize the importance of studying the impacts of climate oscillations in different seasons and different phase combinations. The results indicate that more intense extremes, beyond those already observed, can happen due to these combinations. Such information is important for planning the use and storage of water resources in the short, medium and long term, depending on the periods of such oscillations, and preparing for water emergencies.

\section{MATERIAL AND METHODS}

\section{Material}

Precipitation data used are monthly and quarterly totals, made available by the National Meteorological Institute (INMET, Brazil) and by the Weather Forecast and Climate Studies Center (CPTEC/INPE, Brazil).

Opposite phases of the analyzed climate oscillations are characterized by oceanic and atmospheric variables. Oceanic data are from the National Ocean and Atmospheric Administration Extended Reconstructed SST V4 (NOAA ERSST-V4, Huang et al., 2015) and HadISST1.1 (Rayner et al., 2003) sets. Atmospheric data were obtained from the NCEP/NCAR Reanalysis data set (Kalnay et al., 1996). All these data are provided by the NOAA/ 
OAR/ESRL PSL, Boulder, Colorado, USA, from their website (Physical Sciences Laboratory, 2020a). The indexes representing the Atlantic Multidecadal Oscillation and Interdecadal Pacific Oscillation were obtained from the same institution (Physical Sciences Laboratory, 2020b).

\section{Methods}

The 2020 drought in the period FMA and associated SST pattern is described through precipitation and SST anomalies, which are deviations from the 1981-2010 climatology.

The state of the atmosphere and oceans during the two types of El Niño (EEN and CEN) is characterized through anomaly composites (anomaly means) over events of these phenomena. The events are defined as in Tedeschi et al. $(2015,2016)$, according to the position of the largest SST anomalies in the equatorial belt of the Eastern Pacific $\left(140^{\circ} \mathrm{W}-90^{\circ} \mathrm{W}, 5^{\circ} \mathrm{N}-5^{\circ} \mathrm{S}\right)$ or the Central Pacific $\left(160^{\circ} \mathrm{E}-150^{\circ} \mathrm{W}, 5^{\circ} \mathrm{N}-5^{\circ} \mathrm{S}\right)$, and are the same determined in those studies. These regions correspond, respectively, to most of that for Niño 3 index (with less $10^{\circ}$ at the west side, to separate the regions and thus better distinguish the two types of ENSO), and to that for Niño4 index. An El Niño (La Niña) event is characterized if the five-month running means of monthly SST anomalies in each region are equal or greater than $0.5 \mathrm{~K}$ (equal or less than $-0.5 \mathrm{~K}$ ) for at least six consecutive months (including October-November-December of the beginning year (0) of the event and January of the following year $(+1)$ ). It is called Central ENSO (Central El Niño or Central La Niña) if the anomalies satisfy the conditions in the Central Pacific (Niño 4) region, and East ENSO (East El Niño or East La Niña) if the conditions are satisfied in the Eastern Pacific (approximately Niño3) region. Some episodes satisfy the conditions in both regions. In these cases, the annual anomaly (August (0) to July $(+)$ ) is calculated in each region (Central and East), and the episode is defined according to the region with the highest value.

Since the Atlantic Multidecadal Oscillation (AMO) and Interdecadal Pacific Oscillation (IPO) are the first global scale modes of SST interdecadal variability (e.g., Parker et al., 2007), frequently these modes are represented by indexes based on SST averaged over the regions in which these modes display the largest SST variability. The AMO index is basically an index of the SST anomalies area weighted averaged over the North Atlantic, 0 to $70^{\circ} \mathrm{N}$ (Enfield et al., 2001). The IPO index is based on the difference between the SST anomalies averaged over the central equatorial Pacific $\left(10^{\circ} \mathrm{S}-10^{\circ} \mathrm{N}, 170^{\circ} \mathrm{E}-90^{\circ} \mathrm{W}\right)$ and those average in the Northwest and Southwest Pacific $\left(25^{\circ} \mathrm{N}-45^{\circ} \mathrm{N}, 140^{\circ} \mathrm{E}-145^{\circ} \mathrm{W}\right.$ and $50^{\circ} \mathrm{S}-15^{\circ} \mathrm{S}, 150^{\circ} \mathrm{E}-160^{\circ} \mathrm{W}$, respectively), using HadISST1.1 data (Henley et al., 2015). The data used span the period 1950-2020.

The SST patterns associated with the interdecadal oscillations AMO and IPO are characterized through the correlation between the indexes of these modes and the global SST in grid points from the HadISST1.1 set (Rayner et al., 2003). The relationship of these oscillations with precipitation at the global level is characterized by the correlation between their indexes and the outgoing long-wave radiation (OLR), a variable that satisfactorily represents precipitation in tropical/subtropical regions. The negative anomalies of this radiation are generally related to the weaker thermal radiation emitted from the cold tops of deeper clouds associated with stronger precipitation, while positive anomalies are generally related to the stronger thermal radiation coming from the surface, in cloudless regions and, therefore, without rain. Therefore, negative correlation with OLR means positive correlation with precipitation and vice versa.

\section{RESULTS AND DISCUSSION}

\section{State of the climate in southern Brazil in February- March-April 2020}

In FMA 2020, there was a persistent and intense drought in southern Brazil (Figure 1, upper left panel). It covered almost the entire region. Although there were also some dry months in 2019 (in late winter and early spring), the greatest persistence and extent of drought occurred in FMA 2020, as it was strong and present in all these months (Figure 1, lower panels).

During this period, SST anomalies occurred in regions connected with the climate oscillations CEN, AMO and IPO (Figure 1, upper right panel).

The period from October 2019 to April 2020 was characterized by the NOAA Climate Prediction Center (NOAA/CPC) as an El Niño event, according to the general criterion that the Oceanic Niño Index (ONI) (average three-months SST anomaly over the Niño 3.4 region $\left(5^{\circ} \mathrm{N}-5^{\circ} \mathrm{S}, 120^{\circ}-170^{\circ} \mathrm{W}\right)$ ), is above $0.5 \mathrm{~K}$ (National Weather Service, 2020).

Analyzing the average SST anomalies during the event over the regions in the equatorial Pacific, it is possible to conclude that this event was a weak CEN, since the SST anomalies in the central Pacific (Niño 4 region) were much stronger than in eastern Pacific (Niño 3 region). Precipitation anomalies in southern Brazil were even weakly positive on average in the spring 2019 (OctoberNovember-December), but in late summer and early autumn 2020, anomalies became consistently negative across the region according to the expected behavior for CEN (Tedeschi et al., 2016).

Besides the warming in the central equatorial Pacific, associated with the CEN, there are also positive SST anomalies in the extratropics of the North and South Pacific, associated with the negative phase of the IPO, and in the North Atlantic, associated with the positive phase of the AMO. There is a tendency towards cooling in the eastern Pacific, which is also characteristic of the negative phase of the IPO, although the values are small in this region.

The characteristics and effects of the climate oscillations that most contributed to the drought are described in the next section.

\section{Effects of climate oscillations on precipitation in southern Brazil}

The drought that culminated during FMA resulted from the superposition of effects, in southern Brazil, of different climate oscillations that involve changes in the SST at different time scales: the interannual oscillation ENSO (through a CEN episode), and the two most important global modes of SST interdecadal variability: the AMO and the IPO. 


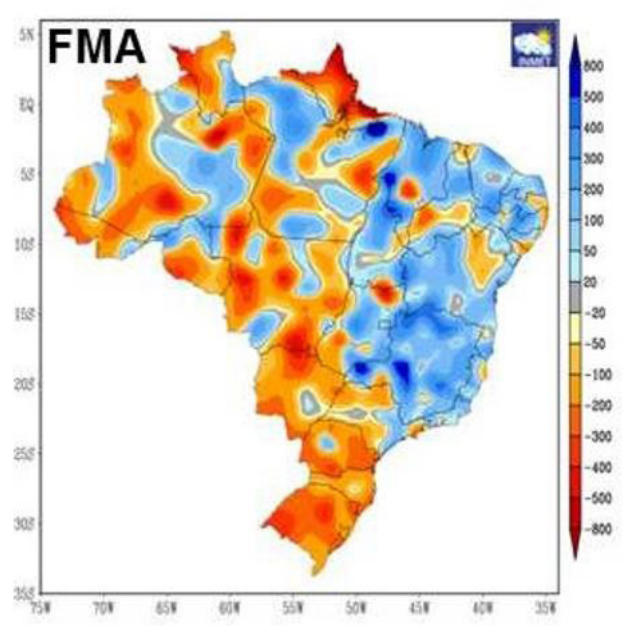

\section{Situation Februay-March-April 2020}
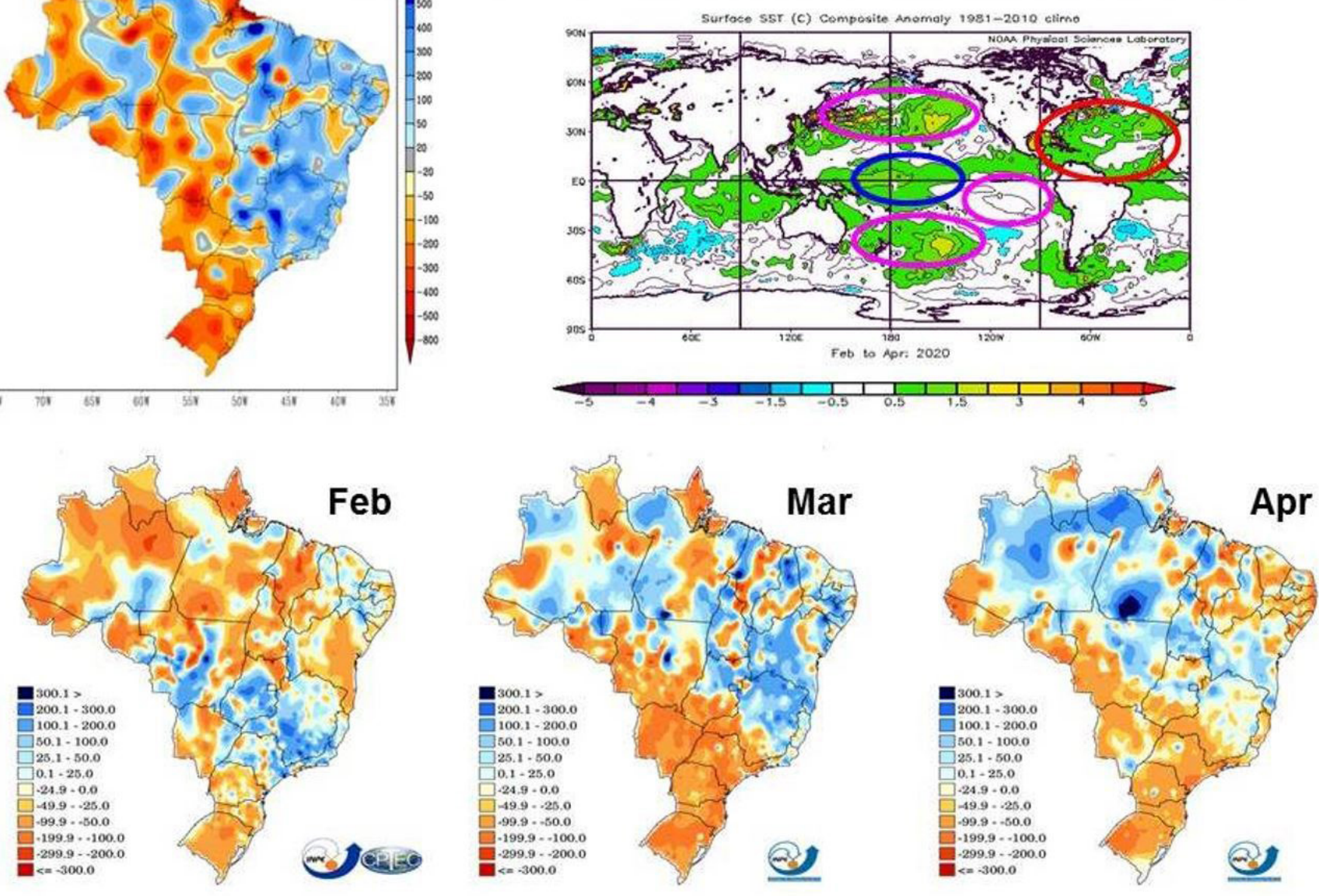

Figure 1. Precipitation anomalies on FMA 2020 (top left panel, from INMET, in mm/trimester) and on February, March and April 2020 (bottom panels, from CPTEC/INPE, in mm/month). The top right panel shows the SST anomalies observed in FMA. The ellipses of different colors indicate the main regions in which different climate oscillations contribute to SST anomalies: CEN (blue), IPO (lilac), AMO (red) (see text) (from the NOAA/ESRL Physical Sciences Laboratory).

\section{Central El Niño}

Figure 2 shows the difference between the two types of El Niño for FMA, through anomaly composites of SST and OLR (indicating precipitation) for these events, defined here according to Tedeschi et al. $(2015,2016)$. The upper panels of Figure 2 show that EEN has SST anomalies in general stronger than CEN, extending from the Central Pacific to the west coast of South America. In CEN the positive equatorial SST anomalies are concentrated in the Central Pacific, with even negative anomalies in the far east of the Pacific. Such differences produce different distributions of anomalous convection over the Pacific, represented in the lower panels of Figure 2 by OLR anomalies. Negative anomalies (in shades of blue, purple and lilac) represent enhanced convection, with more deep clouds and rain, while positive OLR anomalies (in shades of green, yellow and red) indicate more subsidence, less clouds and rain. For EEN, the equatorial anomalous convection in the Pacific extends from the central Pacific to South America, with anomalous subsidence in the subtropics and the equatorial western Pacific. For CEN, the enhanced equatorial convection is only in the Central Pacific and the subsidence in the subtropics also does not extend to South America. On the contrary, in the eastern Pacific the pattern of convection anomalies is reversed, with greater subsidence in the equator and convection in the subtropics.

In the lower panels of Figure 2 it is possible to distinguish the different effects of the two types of El Niño during FMA in southern Brazil, through OLR anomalies over the region (inside the red ellipse). While in the EEN the OLR anomalies are negative (and therefore those of precipitation are positive), in CEN they are positive (and those of precipitation are negative). These results are consistent with those of Tedeschi et al. (2016) for autumn (MAM), using observed rainfall data for South America.

The different impacts in southern Brazil are related to the different distribution of convection anomalies in the Pacific, as they produce different teleconnections that result in distinct atmospheric disturbances over the extratropics of South America (Figure 3). During EEN there is a cyclone (low pressure) to the southwest of the continent and an anticyclone (high pressure) to the southeast; in CEN the opposite occurs, with an anticyclone to the southwest and a cyclone to the southeast. The difference stems from the different wave propagation from the eastern tropical Pacific, as there are different convection anomalies there, 
East EI Niño
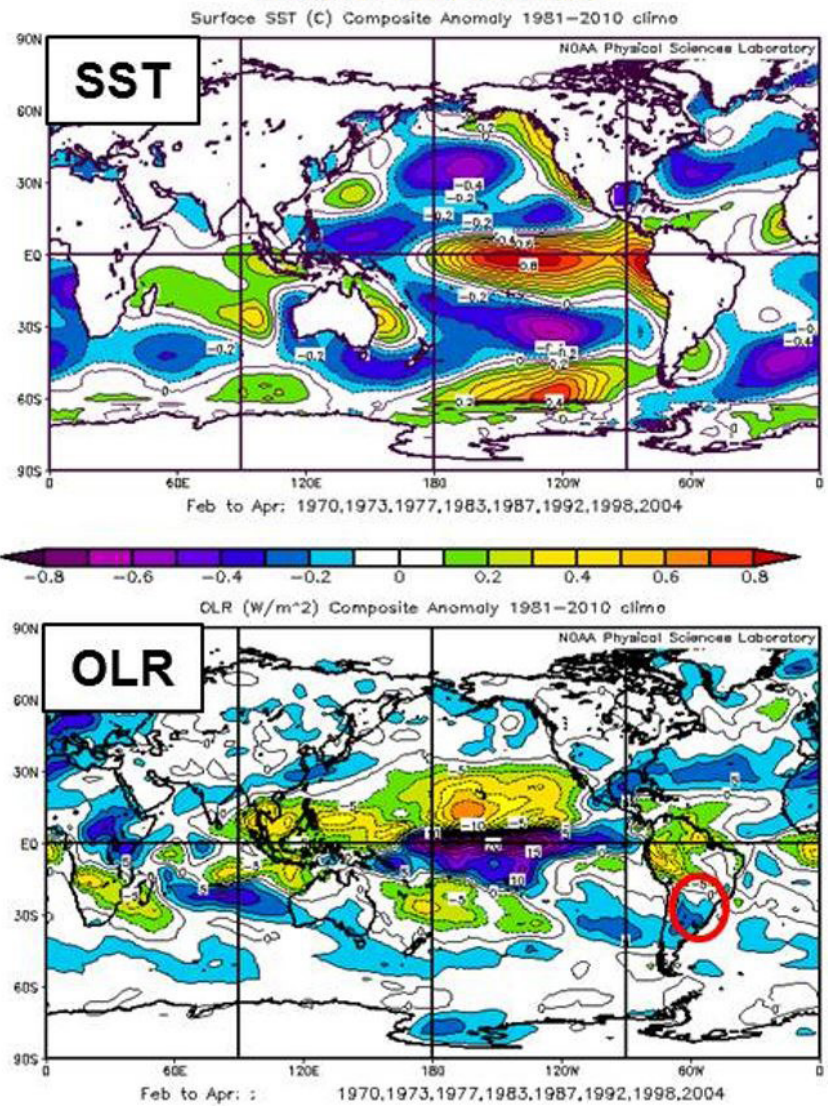

Feb to Apr: : $\quad 1970.1973 .1977 .1983 .1987 .1992,1998.2004$
Central EI Niño
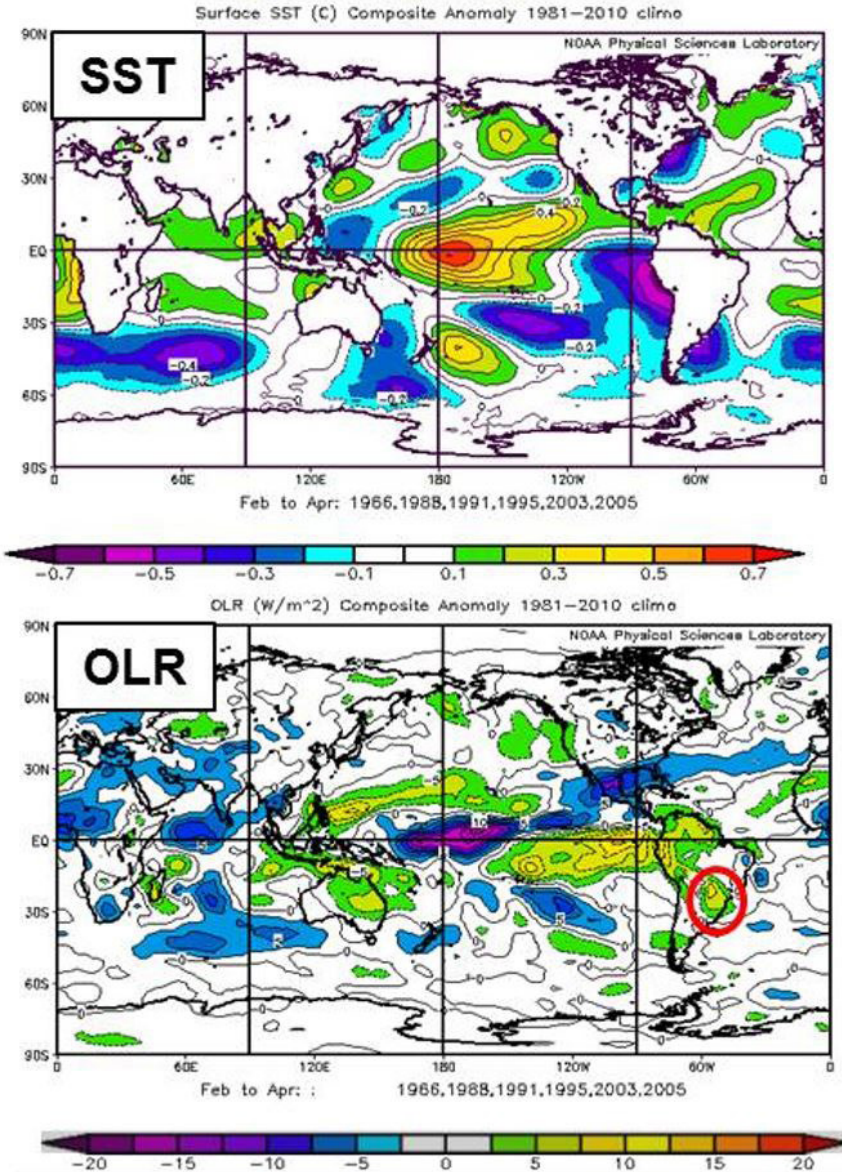

Figure 2. Characteristics of East El Niño (EEN) and Central El Niño (CEN) for February-March-April, with regard to: (top panels) sea surface temperature (SST) anomalies $(\mathrm{K})$ and (bottom panels) outgoing long-wave radiation (OLR) anomalies $\left(\mathrm{W} / \mathrm{m}^{2}\right)$, whose negative (positive) values indicate positive (negative) precipitation anomalies (from the NOAA/ESRL Physical Sciences Laboratory). The red ellipse highlights southern Brazil. For EEN the equatorial anomalous warm SST and enhanced convection extend from Central Pacific to South America, while for CEN they are concentrated in Central Pacific. As a consequence, in EEN (CEN) precipitation anomalies are positive (negative) over southern Brazil.

East El Niño

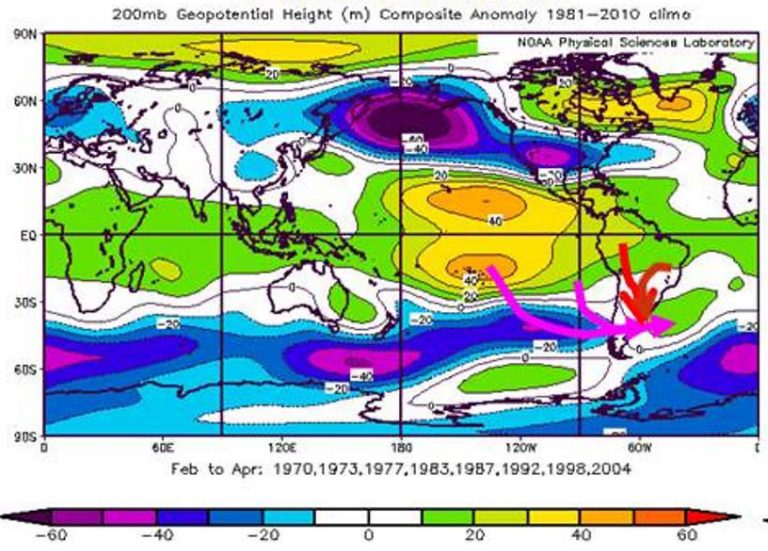

Central El Niño

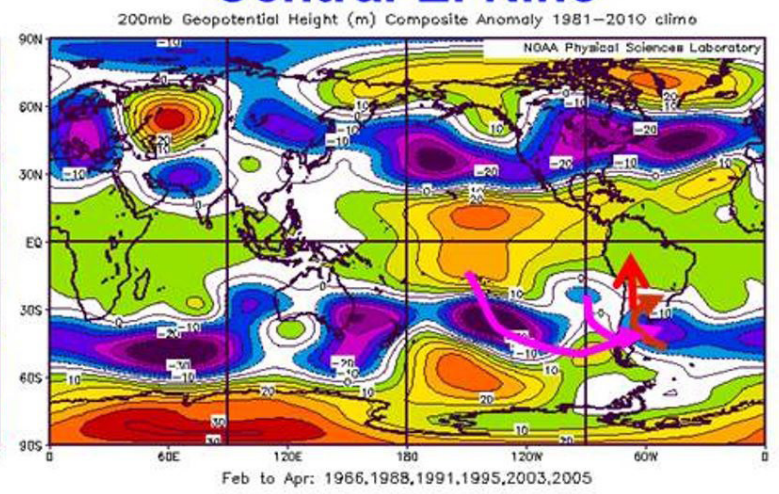

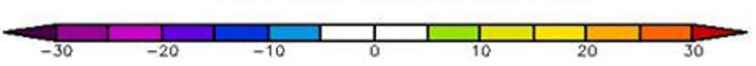

Figure 3. Geopotential anomalies at high level (200 hPa) for February-March-April of (left) EEN and (right) CEN (from the NOAA/ ESRL Physical Sciences Laboratory). Positive (negative) anomalies indicate regions of higher (lower) pressure, with anticyclonic (cyclonic) circulation. The lilac lines indicate Rossby wave propagation relevant to southern South America, showing a west-east pair cyclone/ anticyclone (anticyclone/cyclone) straddling extratropical South America for EEN (CEN). Since in the extratropics the Rossby waves have equivalent barotropic structure, this pair also exists at low-level. Therefore, red lines indicate circulation and moisture transport anomalies contributing to precipitation anomalies in southern Brazil. 
which modify the resulting Rossby wave that reaches southern South America. This region in the eastern Pacific is important for the propagation of teleconnections to the extratropics of South America, since it is one of the few equatorial regions with westerly winds at high levels, which facilitate the propagation of Rossby waves to higher latitudes. Anomalies over southern South America are, in reality, more influenced by convection anomalies in the eastern equatorial Pacific than in the central Pacific (Grimm \& Silva Dias, 1995; Grimm \& Ambrizzi, 2009).

In the extratropics, circulation anomalies caused by Rossby waves are equivalent barotropic, that is, they have the same sign of anomalies at low and high levels (Grimm \& Silva Dias, 1995; Ting, 1996). In the case of EEN, the upper-level pattern with a cyclone to the southwest and anticyclone to the southeast of South America stimulates ascending motion over the subtropics of the continent, east of the Andes, via advection of cyclonic vorticity, which favors ascending motion to the east of the cyclonic anomaly (Holton, 2004; Grimm, 2003; Tedeschi et al., 2016). At low-level, the cyclone/anticyclone pair enhances the transport of moisture from the north to southern Brazil (red lines), producing moisture convergence and favoring precipitation in this region (Grimm, 2003; Tedeschi et al., 2016). In the case of CEN, the pattern with an anticyclone to the southwest and cyclone to the southeast of South America favors the opposite: subsidence over southern Brazil and moisture transport from this region to the north, resulting in reduced precipitation.

It is interesting to note that the greatest differences between the impacts of EEN and CEN occur in the fall/winter of the year following the start of the events, since it is in this period that the greatest differences between the SST anomalies in the eastern equatorial Pacific occur for the two types of EN, while the differences are smaller in the spring of the event (Tedeschi et al., 2015, 2016).
Atlantic Multidecadal Oscillation (AMO)

The quasi-interhemispheric structure of opposite SST anomalies in the Atlantic Basin displaces the Intertropical Convergence Zone (ITCZ) northward, and creates anomalies of meridional circulation between the two hemispheres. There are important AMO impacts on the precipitation over the tropical/ subtropical Atlantic basin, which follow from the meridional shifts of the Atlantic ITCZ. Over South America, the strongest anomalies occur over Northeast Brazil, whose rainy season depends on the position of the ITCZ, but they also extend over southern Brazil.

Figure 4 shows, through correlation analysis with the AMO index, the SST anomalies associated with this oscillation in the FMA trimester (left panel), as well as the convection (or precipitation) anomalies represented by OLR anomalies (right panel). The positive correlation with OLR (which is negatively correlated with precipitation), means that in the AMO positive phase $(\mathrm{AMO}(+))$, observed in FMA 2020, there is reduced precipitation in FMA over southern Brazil (red ellipse).

This mode influences the first modes of interdecadal monsoon precipitation variability over South America, as can be seen in Grimm \& Saboia (2015) and Grimm et al. (2016), in which the first two summer modes display negative anomalies over southern Brazil corresponding to positive AMO phase.

Interdecadal Pacific Oscillation (IPO)

Since there are similarities between EEN and IPO positive phase anomalous SST patterns (cf. Figures 2 and 5 (left)) there are also similar influences on the precipitation, here represented by OLR. Remembering that OLR and precipitation anomalies are negatively correlated, it is possible to see that the FMA precipitation

Atlantic Multidecadal Oscillation (AMO)
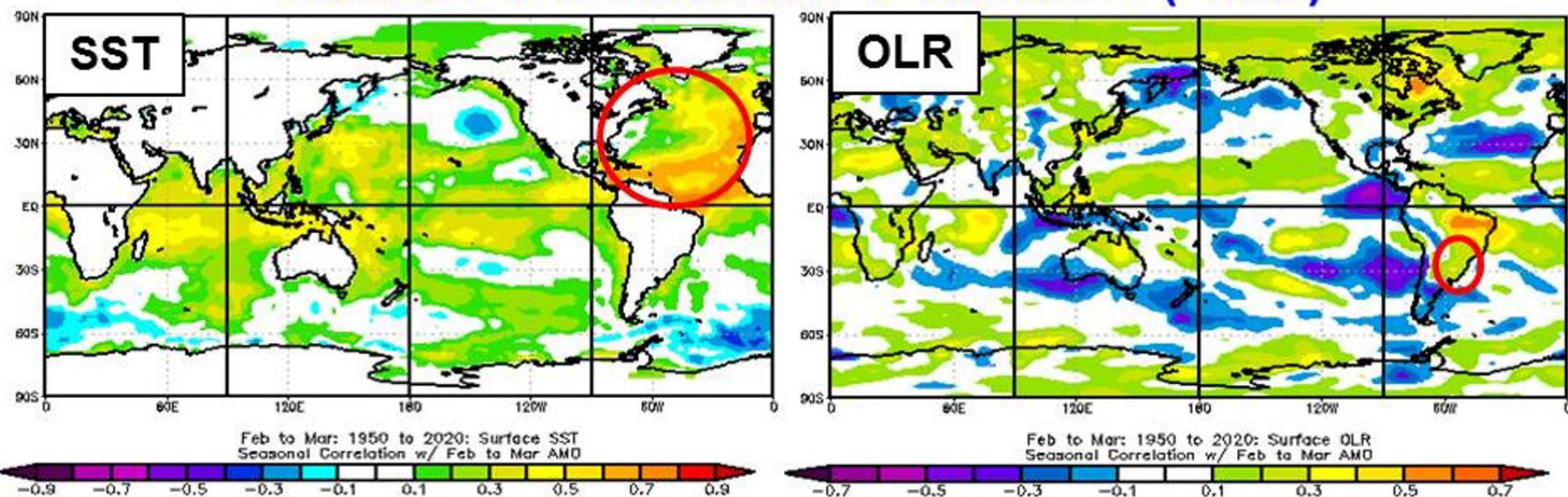

Figure 4. Correlation of the AMO index with (left) SST and (right) OLR, during February-March-April, indicating the sign of the anomalies associated with the positive phase of the AMO (from the NOAA/ESRL Physical Sciences Laboratory). The ellipse on the left panel indicates the region with highest components of the oscillation (North Atlantic), while on the right panel it highlights southern Brazil, where positive correlation with OLR indicates negative correlation with precipitation. Correlations equal to 0.20 are significant to the 0.05 level. Therefore, the positive correlation with OLR above 0.2 in southern Brazil means that the positive phase of AMO produces reduced precipitation in this region. 

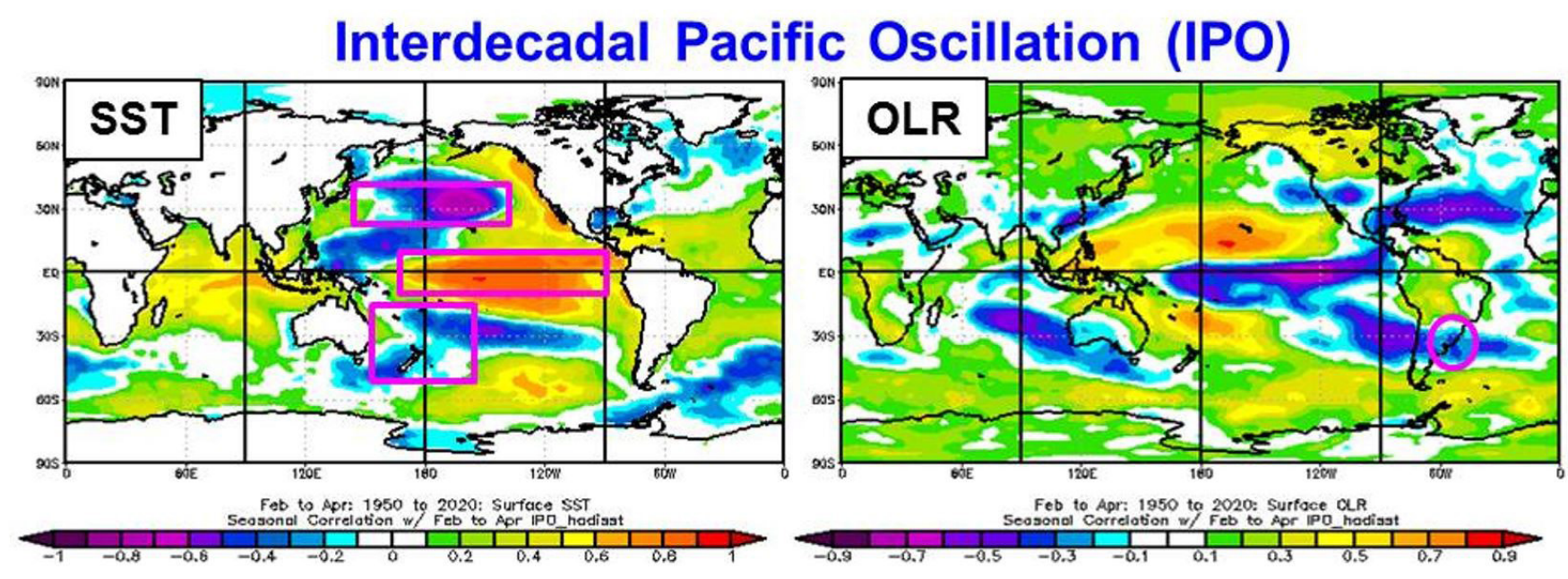

Figure 5. Correlation of the IPO index with (left) SST and (right) OLR, during February-March-April, indicating the sign of the anomalies associated with the positive phase of the IPO (from the NOAA/ESRL Physical Sciences Laboratory). The rectangles on the left panel show the areas used in the definition of the IPO index. The ellipse on the right panel highlights southern Brazil, where negative correlation with OLR indicates positive correlation with precipitation. Correlations equal to 0.20 are significant to the 0.05 level. Therefore, the negative correlation with OLR below -0.2 in southern Brazil means that the positive phase of IPO produces increased precipitation in this region.

anomaly patterns associated with the IPO positive phase and EEN are similar over South America, with positive (negative) values over the subtropical (northern/central-west) parts of the continent. Therefore, the IPO negative phase (IPO(-)), observed in FMA 2020, would produce reduced precipitation over southern Brazil.

Combined effect of climate oscillations on precipitation variability and extremes

The combined effects of CEN, AMO (+) and IPO (-) in FMA are stronger, more comprehensive and consistent in southern Brazil (Figure 1) because it is in this region that the effects of these oscillations in these phases coincide in producing reduced precipitation. In other regions the influences are mixed. For example, in most of the western and northern parts of Brazil, AMO (+) and IPO (-) produce opposite effects on FMA rainfall (Figures 4 and 5), while CEN favors reduced precipitation (Figure 2). The result is mixed signs, with some prevalence of negative anomalies (Figure 1). In the eastern part, there is little influence of IPO, although IPO(-) enhances rainfall in the southern part of southeast Brazil and eastern part of North Brazil (Figure 5), contrary to AMO (+) (Figure 4), and although CEN produces few anomalies in the eastern part (Figure 2), they are positive. In this part, positive anomalies predominate, although most are weak (Figure 1). ENSO has more impact on the variance of seasonal precipitation than interdecadal oscillations. The latter can modulate the former but this does not preclude the occurrence of ENSO events with opposite effects to those of the interdecadal oscillations, as shows the analysis in the following.

Both modes, AMO and IPO, influence the first two modes of monsoon precipitation interdecadal variability over South America, but with different combination of phases, as can be seen in Grimm \& Saboia (2015) and Grimm et al. (2016). While in the first mode both oscillations are in the same phase, in the second one they are in opposite phases, which is even more effective in producing anomalies over southern Brazil in austral autumn. Although the dynamical mechanisms of the AMO and IPO impacts on the precipitation over southern Brazil is not within the scope of this study, it is interesting to mention that the influence of $\mathrm{AMO}(+)$ and $\mathrm{IPO}(-)$ on the second interdecadal mode of monsoon precipitation produces a low level divergence center over central South America (and upper-level convergence center) which weakens the monsoon circulation and reduces the precipitation, especially in the subtropics (see Figures $5 \mathrm{f}-\mathrm{j}$ in Grimm et al. (2016) and corresponding analysis). The time evolution of this precipitation mode also displays phase changes in the late 1970s and late 1990s (Figure 3b in Grimm et al. (2016)), as shown for AMO and IPO in Figure 6.

It is interesting to compare the evolution of the AMO and IPO indexes (Figure 6, upper panel) and the FMA precipitation interdecadal variability in two separate areas of southern Brazil, which show that the behavior is consistent over this region (Figure 6, bottom panels). The evolution of AMO and IPO in the period 1950-2020 is smoothed by a 4-year moving average, to emphasize the slowest variations, but their phases remained respectively positive and negative in FMA 2020, as the most recent averages in Figure 6. It is possible to see that in decades with predominant AMO(-) and $\mathrm{IPO}(+)$ (late 1970s till late 1990s) the precipitation in the region was enhanced, but when these oscillations changed phase to $\mathrm{AMO}(+)$ and $\mathrm{IPO}(-)$ in the late 1990 s, precipitation was reduced in the following decades. This combined effect of the two oscillations is consistent with the superposition of the effects previously described produced by each oscillation on the precipitation in southern Brazil. 

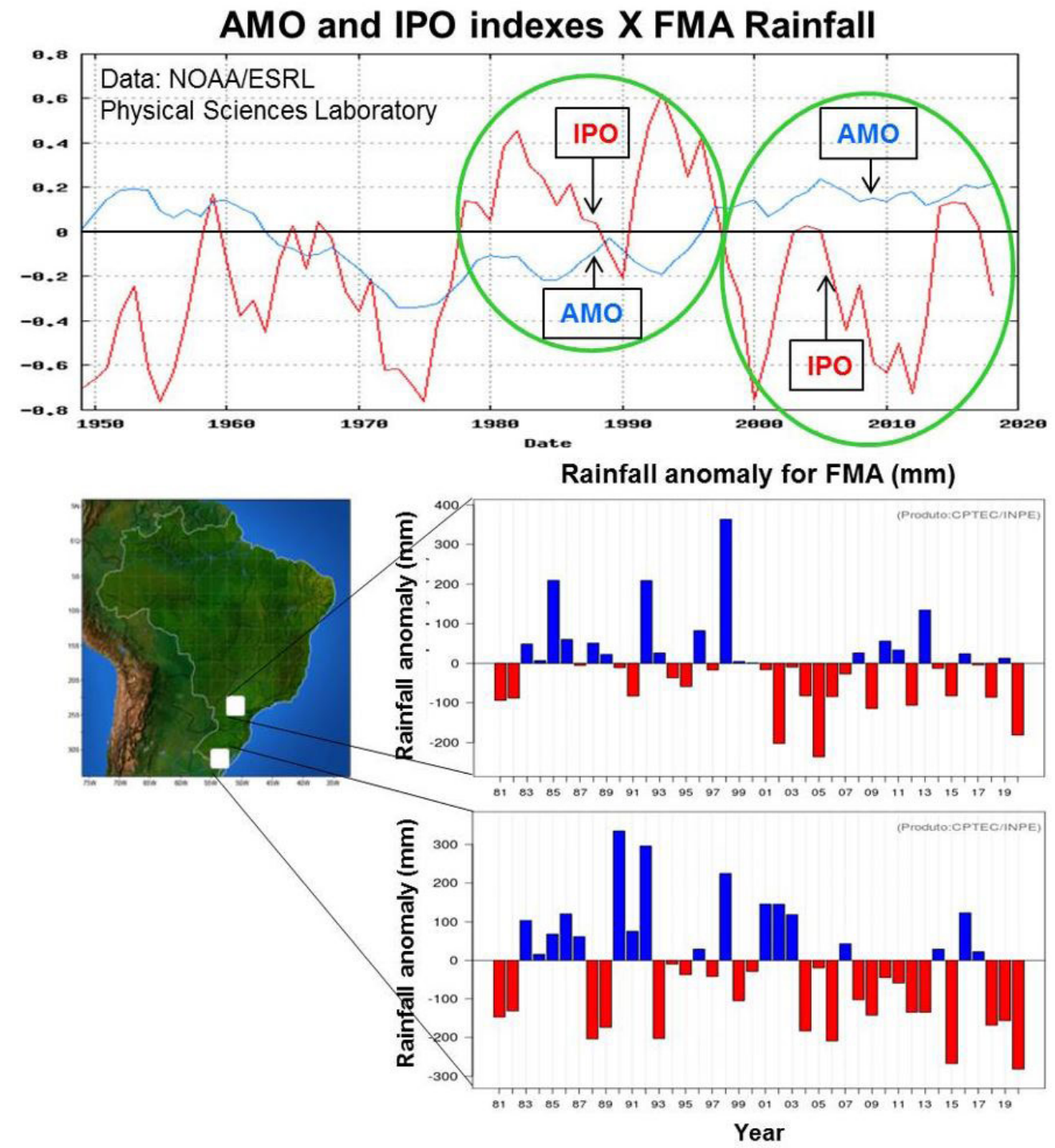

Figure 6. (Upper panel) Indexes representing AMO (blue line) and IPO (red line) in the period 1950-2020, smoothed with a 4-years running mean (from the NOAA/ESRL Physical Sciences Laboratory). The periods late 1970s - late 1990s and late 1990s - 2020, in which the two oscillations had opposite phases, are limited by green ellipses. (Bottom panels) FMA rainfall anomaly series averaged over two areas marked on the map (from CPTEC/INPE). In the decades with predominant IPO positive phase and AMO negative phase rainfall anomalies were predominantly positive (blue bars), while in those with predominant IPO negative phase and AMO positive phase they were predominantly negative (red bars).

The influence of these slow climate oscillations is due to changes in the basic state of the atmosphere produced by different SST boundary conditions. This does not mean that extremes (of drought or precipitation) cannot occur in the opposite direction to that favored by the combination of phases of interdecadal oscillations, but these will generally be less frequent and less intense. Therefore, in periods when these climate oscillations favor above (below) normal rainfall, large accumulations (severe droughts) are more frequent. This relationship between climate oscillations and extreme precipitation events occurs for interdecadal (Grimm et al., 2016), interannual (Grimm \& Tedeschi, 2009; Tedeschi et al., 2015, 2016) and intraseasonal (Grimm, 2019) time scales. This is why it is so important to know it for different seasons and phase combinations, as it establishes the extreme limits for which water resources managers must plan.
In addition to the combination of interdecadal oscillations that produce an atmospheric basic state favorable to drought, the occurrence of a really severe drought usually also counts on the combined occurrence of a favorable climatic event on interannual scale, such as CEN in 2020 or La Niña in 2009 and 2012. A similar condition is valid for producing large accumulations of precipitation, when a phase combination of interdecadal oscillations favorable to enhanced precipitation is completed with the occurrence of a favorable climatic event on interannual or intraseasonal time scale, such as EEN in 1992 and 1998. However, an interdecadal context favorable to deficient (excess rainfall) does not preclude the occurrence of an interannual oscillation episode leading to excess (deficient) rainfall, as EEN in 2016 (La Niña in 1989), although the resulting rainfall anomalies may be reduced. 


\section{Possible role of anthropogenic climate change}

Although a particular extreme drought cannot be attributed to anthropogenic causes, they may have influence on changing the intensity and frequency of these extreme events (e.g., Skansi et al., 2013). For example, extensive deforestation in the Amazon affects evapotranspiration from the Amazon basin and alters the cascading moisture recycling, which involves re-evaporation cycles along the way of the moisture transport from the tropical Atlantic and the entire Amazon basin towards the Paraná-La Plata basin. According to Zemp et al. (2014), this moisture recycling contributes about $17-18 \%$ to the precipitation over the La Plata basin, and increases the fraction of precipitation over the La Plata basin that originates from the Amazon basin from 18-23 to 24-29\% during the wet season. Therefore, deforestation can change the amount of moisture that comes from the Amazon to the Paraná/ Plata Basin, and droughts produced by natural oscillations can be intensified in southern Brazil.

\section{CONCLUSIONS}

Within the interdecadal context of an atmospheric basic state more favorable or unfavorable to precipitation in a certain region, the occurrence of interannual or intraseasonal time scale climate events (such as El Niño, La Niña, or different phases of the Madden-Julian Oscillation) that produce effects in the same direction as the interdecadal oscillations, may lead to extreme events of rainfall or drought. Climate oscillations and some of their combinations alter the frequency (and sometimes the intensity) of synoptic events that most influence the weather in the region, such as cold fronts in southern Brazil, producing different amounts of precipitation. It is important that water resource managers are aware of the possible effects of different combinations of climate oscillations on extremes. These effects change according to the season and to the phases of the oscillations, requiring detailed study of possible interactions.

In the present case study not all of the natural global or regional climate oscillations that explain smaller amounts of low-frequency climate variability than AMO, IPO and ENSO were in a phase favorable to drought in southern Brazil, which means that other combinations may produce even more extreme events. Preparing for water emergencies requires that managers have an idea of how extreme such emergencies can be, and this depends on the study of the effects of possible combinations of climate oscillations.

\section{ACKNOWLEDGEMENTS}

The first author thanks funding from CNPq and IAI grant CRN3035, which is supported by US NSF Grant GEO-1128040.

\section{REFERENCES}

Agência Nacional de Águas - ANA. (2020). Séries Históricas de Estações (Portal HidroWeb v3.1.1). Retrieved in 2020, July 15, from http://www.snirh.gov.br/hidroweb/serieshistoricas
Cai, W., Mcphaden, M. J., Grimm, A. M., Rodrigues, R. R., Taschetto, A. S., Garreaud, R. D., Dewitte, B., Poveda, G., Ham, Y.-G., Santoso, A., Ng, B., Anderson, W., Wang, G., Geng, T., Jo, H.-S., Marengo, J. A., Alves, L. M., Osman, M., Li, S., Wu, L., Karamperidou, C., Takahashi, K., \& Vera, C. (2020). Climate impacts of the El Niño-Southern Oscillation on South America. Nature Reviews Earth \& Environment, 1(4), 215-231. http://dx.doi.org/10.1038/ s43017-020-0040-3.

Centro Nacional de Monitoramento e Alertas de Desastres Naturais - CEMADEN. (2020a). Boletim de impactos em atividades estratégicas para o Brasil (No. 18). São José dos Campos. Retrieved in 2020, July 15, from http://www.cemaden.gov.br/wp-content/uploads/2020/04/ Boletim18_Impactos_20200408.pdf

Centro Nacional de Monitoramento e Alertas de Desastres Naturais - CEMADEN. (2020b). Boletim de impactos em atividades estratégicas para o Brasil (No. 19). São José dos Campos. Retrieved in 2020, July 15, from http://www.cemaden.gov.br/wp-content/uploads/2020/05/ Boletim19_Impactos_20200508-1.pdf

Centro Nacional de Monitoramento e Alertas de Desastres Naturais - CEMADEN. (2020c). Boletim de impactos em atividades estratégicas para o Brasil (No. 20). São José dos Campos. Retrieved in 2020, July 15, from http://www.cemaden.gov.br/wp-content/uploads/2020/06/ Boletim20_Impactos_20200610.pdf

Companhia Paranaense de Energia Elétrica - COPEL. (2020). Monitoramento hidrológico. Curitiba. Retrieved in 2020, July 15, from https://www.copel.com/mhbweb/paginas/bacia-iguacu.jsf

Enfield, D. B., Mestas-Nunez, A. M., \& Trimble, P. J. (2001). The Atlantic Multidecadal Oscillation and its relationship to rainfall and river flows in the continental U.S. Geophysical Research Letters, 28(10), 2077-2080. http://dx.doi.org/10.1029/2000GL012745.

Grimm, A. M. (2003). The El Niño impact on the summer monsoon in Brazil: regional processes versus remote influences. Journal of Climate, 16(2), 263-280. http://dx.doi.org/10.1175/15200442(2003)016<0263:TENIOT>2.0.CO;2.

Grimm, A. M. (2004). How do La Niña events disturb the summer monsoon system in Brazil? Climate Dynamics, 22(2-3), 123-138. http://dx.doi.org/10.1007/s00382-003-0368-7.

Grimm, A. M. (2011). Interannual climate variability in South America: impacts on seasonal precipitation, extreme events and possible effects of climate change. Stochastic Environmental Research and Risk Assessment, 25(4), 537-554. http://dx.doi.org/10.1007/ s00477-010-0420-1.

Grimm, A. M. (2019). Madden-Julian Oscillation impacts on South American summer monsoon season: precipitation anomalies, extreme events, teleconnections, and role in the MJO cycle. Climate Dynamics, 53(1-2), 907-932. http://dx.doi.org/10.1007/s00382-019-04622-6.

Grimm, A. M., \& Ambrizzi, T. (2009). Teleconnections into South America from the tropics and extratropics on interannual and 
intraseasonal timescales. In F. Vimeux, F. Sylvestre \& M. Khodri (Eds.), Past climate variability in South America and surrounding regions: from the last glacial maximum to the holocene (Developments in Paleoenvironmental Research, No. 14, Cap. 7, pp. 159-193). Netherlands: Springer. http://dx.doi.org/10.1007/978-90-481-2672-9_7.

Grimm, A. M., \& Saboia, J. P. J. (2015). Interdecadal variability of the South American precipitation in the monsoon season. Journal of Climate, 28(2), 755-775. http://dx.doi.org/10.1175/JCLI-D-14-00046.1.

Grimm, A. M., \& Silva Dias, P. L. (1995). Analysis of tropicalextratropical interactions with influence functions of a barotropic model. Journal of the Atmospheric Sciences, 52(20), 3538-3555. http:/ / dx.doi.org/10.1175/1520-0469(1995)052<3538:AOTIWI>2.0.CO;2.

Grimm, A. M., \& Tedeschi, R. G. (2009). ENSO and extreme rainfall events in South America. Journal of Climate, 22(7), 1589-1609. http:/ / dx.doi.org/10.1175/2008JCLI2429.1.

Grimm, A. M., Laureanti, N. C., Rodakoviski, R. B., \& Gama, C. B. (2016). Interdecadal variability and extreme precipitation events in South America during the monsoon season. Climate Research, 68(2-3), 277-294. http://dx.doi.org/10.3354/cr01375.

Henley, B. J., Gergis, J., Karoly, D. J., Power, S. B., Kennedy, J., \& Folland, C. K. (2015). A tripole index for the interdecadal pacific oscillation. Climate Dynamics, 45(11-12), 3077-3090. http://dx.doi. org/10.1007/s00382-015-2525-1.

Holton, J. R. (2004). An introduction to dynamic meteorology (4th ed.). San Diego: Elsevier.

Huang, B., Banzon, V. F., Freeman, E., Lawrimore, J., Liu, W., Peterson, T. C., Smith, T. M., Thorne, P. W., Woodruff, S. D., \& Zhang, H.-M. (2015). Extended Reconstructed Sea Surface Temperature version 4 (ERSST.v4): Part I. Upgrades and intercomparisons. Journal of Climate, 28(3), 911-930. http://dx.doi.org/10.1175/JCLI-D-14-00006.1.

Instituto Brasileiro de Geografia e Estatística - IBGE. (2020). Levantamento sistemático da produção agrícola. Retrieved in 2020, July 15, from https://sidra.ibge.gov.br/tabela/6588

Kalnay, E., Kanamitsu, M., Kistler, R., Collins, W., Deaven, D., Gandin, L., Iredell, M., Saha, S., White, G., Woollen, J., Zhu, Y., Leetmaa, A., Reynolds, R., Chelliah, M., Ebisuzaki, W., Higgins, W., Janowiak, J., Mo, K. C., Ropelewski, C., Wang, J., Jenne, R., \& Joseph, D. (1996). The NCEP/NCAR 40-year reanalysis project. Bulletin of the American Meteorological Society, 77(3), 437-471. http:/ / dx.doi.org/10.1175/1520-0477(1996)077<0437:TNYRP>2.0.CO;2.

Kao, H.-Y., \& Yu, J.-Y. (2009). Contrasting Eastern-Pacific and Central-Pacific types of ENSO. Journal of Climate, 22(3), 615-632. http://dx.doi.org/10.1175/2008JCLI2309.1.

Knight, J. R., Allan, R. J., Folland, C. K., Vellinga, M., \& Mann, M. E. (2005). A signature of persistent natural thermohaline circulation cycles in observed climate. Geophysical Research Letters, 32(20), L20708. http://dx.doi.org/10.1029/2005GL024233.
National Weather Service. (2020). Retrieved in 2020, July 15, from https://origin.cpc.ncep.noaa.gov/products/analysis_monitoring/ ensostuff/ONI_v5.php

Operador Nacional do Sistema Elétrico - ONS. (2020a). Energia natural afluente por subsistema. Retrieved in 2020, July 15, from http:/ / www.ons.org.br/Paginas/resultados-da-operacao/historico-daoperacao/energia_afluente_subsistema.aspx

Operador Nacional do Sistema Elétrico - ONS. (2020b). Energia armazenada. Retrieved in 2020, July 15, from http://www.ons. org.br/Paginas/resultados-da-operacao/historico-da-operacao/ energia_armazenada.aspx

Parker, D., Folland, C., Scaife, A., Knight, J., Colman, A., Baines, P., \& Dong, B. (2007). Decadal to multidecadal variability and the climate change background. Journal of Geophysical Research, 112(D18), D18115. http://dx.doi.org/10.1029/2007JD008411.

Physical Sciences Laboratory. (2020a) Retrieved in 2020, July 15, from https://psl.noaa.gov/

Physical Sciences Laboratory. (2020b). Retrieved in 2020, July 15, from https://psl.noaa.gov/data/climateindices/list/

Power, S., Casey, T., Folland, C., Colman, A., \& Mehta, V. (1999). Interdecadal modulation of the impact of ENSO on Australia. Climate Dynamics, 15(5), 319-324. http://dx.doi.org/10.1007/ s003820050284.

Rayner, N. A., Parker, D. E., Horton, E. B., Folland, C. K., Alexander, L. V., Rowell, D. P., Kent, E. C., \& Kaplan, A. (2003). Global analyses of sea surface temperature, sea ice, and night marine air temperature since the late nineteenth century. Journal of Geophysical Research, 108(D14), 4407. http://dx.doi.org/10.1029/2002JD002670.

Skansi, M. M., Brunet, M., Sigró, J., Aguilar, E., Arevalo Groening, J. A., Bentancur, O. J., Castellón Geier, Y. R., Correa Amaya, R. L., Jácome, H., Malheiros Ramos, A., Oria Rojas, C., Pasten, A. M., Sallons Mitro, S., Villaroel Jiménez, C., Martínez, R., Alexander, L. V., \& Jones, P. D. (2013). Warming and wetting signals emerging from analysis of changes in climate extreme indices over South America. Global and Planetary Change, 100, 295-307. http://dx.doi. org/10.1016/j.gloplacha.2012.11.004.

Tedeschi, R. G., Grimm, A. M., \& Cavalcanti, I. F. A. (2015). Influence of Central and East ENSO on extreme events of precipitation in South America during austral spring and summer. International Journal of Climatology, 35(8), 2045-2064. http://dx.doi.org/10.1002/joc.4106.

Tedeschi, R. G., Grimm, A. M., \& Cavalcanti, I. F. A. (2016). Influence of Central and East ENSO on precipitation and its extreme events in South America during austral autumn and winter. International Journal of Climatology, 36(15), 4797-4814. http:/ /dx.doi. org/10.1002/joc.4670.

Ting, M. (1996). Steady linear response to tropical heating in barotropic and baroclinic models. Journal of the Atmospheric Sciences, 53(12), 1698- 
1709. http:/ /dx.doi.org/10.1175/1520-0469(1996)053<1698:SLR T'TH>2.0.CO;2.

Yang, Y.-M., An, S.-I., Wang, B., \& Park, J. H. (2020). A global-scale multidecadal variability driven by Atlantic multidecadal oscillation. National Science Review, 7(7), 1190-1197. http://dx.doi.org/10.1093/ nsr/nwz216.

Zemp, D. C., Schleussner, C.-F., Barbosa, H. M. J., Van Der Ent, R. J., Donges, J. F., Heinke, J., Sampaio, G., \& Rammig, A. (2014). On the importance of cascading moisture recycling in South America. Atmospheric Chemistry and Physics, 14(23), 13337-13359. http://dx.doi. org/10.5194/acp-14-13337-2014.

\section{Authors contributions}

Alice Marlene Grimm: Conceived the study and contributed the climatic analysis on the causes of the drought.

Arlan Scortegagna Almeida: Contributed the information on the impacts of the drought and to the discussion.

Cesar Augustus Assis Beneti: Contributed the information on the impacts of the drought and to the discussion.

Eduardo Alvim Leite: Contributed the information on the impacts of the drought and to the discussion. 